\title{
溶接構造物の破損事例とその教訓（1）
}

\author{
一破損事例からの教訓一*
}

矢島浩**

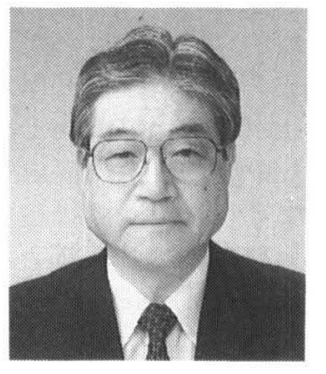

\section{Lessons to Learn from Examples of Damages to Welded Structures [1]*}

\author{
by Hiroshi YAJIMA** \\ キーワード：溶接構造物, 橋梁, 船舶, 海洋構造物, 破損, \\ 脆性不安定破壊, 溶接欠陥, 疲労龟裂, 教訓
}

\section{1. は じめに}

橋梁・船舶・海洋構造物などの大型溶接構造物で発生 した多くの破損例 ${ }^{1,2)}$ は, 工学の世界に幾多の貴重な教訓 を残した。また, 平成 7 年 1 月 17 日早朝の阪神・淡路大 地震による震災 ${ }^{3)}$ は, 身近な事例として, 工学の世界に 貴重な教訓を残した。

21 世紀に向けて, 大型溶接構造物の高信頼性確保と高 付加価值化を実現していくためには, 多くの破損例が残 した教訓を謙虚に受け止めて, 前向きに, 合理的に, 今 後の糧にする必要がある.

大型溶接構造物が“壊れる”ことも, “全寿命において 機能を全うする”ことも, 自然現象であり, それは, 設 計・建造あるいはメンテナンス担当者の能力次第で決ま ク，財力や権力の及ぶところではないからである．自然 現象は正直であり, 絶対に嘘をつかない. また, 絶対に 我慢もしてくれないのである。

橋梁・船舶・海洋構造物などで発生した破損例を数例 紹介し, 原因や問題点について述べ, 工学の世界に残し てくれた教訓について述べる.

\section{Hasselt 橋の破損例}

ベルギーのルーバン大学, A. Vierendeel 教授が企 画・設計し， 1933 年以降, 数年間に 50 橋以上の Vierendeel Truss 橋がベルギー各地に架設された。 長さ約 $74.5 \mathrm{~m}$, 幅約 $10.4 \mathrm{~m}$ の Hasselt 橋（図 1) は, その一つで

*原稿受付 平成 11 年 8 月 1 日

**正貝広島大学工学部 Member, Hiroshima University
あった. 1937 年 (昭和 12 年) 1 月 19 日に載荷試験に合 格して完成したが, 1938 年 (昭和 13 年) 3 月 14 日に路 面電車通過直後に崩落してしまった（幸い死者はなかっ た）ことは，あまりにも有名な事件である ${ }^{1,2,4)}$.

Hasselt 橋には, 最大板厚 $55 \mathrm{~mm}$ のトーマス鋼（引張 強さ：42 $52 \mathrm{kgf} / \mathrm{mm}^{2}$, 降伏点: $28 \mathrm{kgf} / \mathrm{mm}^{2}$ 程度, 伸 び：20\%以上）が使用されていた由であり, 現場工作も 含め,すへてて溶接によって組み立てられていた。

強大な権力をもったボス的教授が企画・設計・推進し たので, チェック機構は何も用をなさなかったものと考 えられている.

架設された Vierendeel Truss 橋は, 数年間で, そのほ とんどが破損したようであり, 工学の世界に強烈な教訓 を残してくれた。

“壊れる”ことは自然現象であり，財力・権力の及ぶと
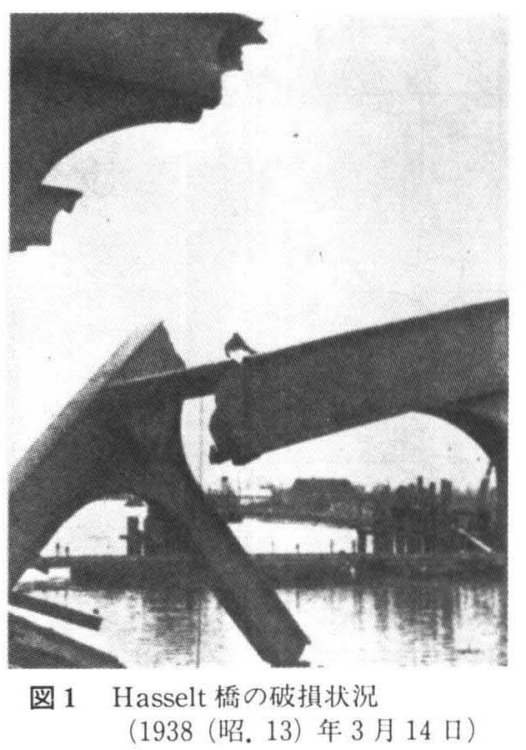
ころではない。また，一人の人間の智力は，自然に対し ては微々たるものである．謙虚に対応すべし．

昭和 $12 \cdot 13$ 年頃, 我が国においても, 溶接はかなり実 用されていた。一歩一歩基礎から積み上げて実用化され たため，このような大きな破損例は経験していない.

\section{3. 米国における戦時標準船の破損例}

第二次世界大戦中, 米国で建造された戦時標準船の脆 性破壊による破損例は, これまたあまりにも有名であ $ろ^{1,2,4,5)}$.

約 5,000 隻建造されたうち, 約 1,000 隻に約 1,500 件 もの損傷 (その多くは, 約 $3 \mathrm{~m}$ 以上の亀裂) が発生した由 であり, そのうち約 250 隻は, 甲板に亀裂が入る船体強 度上重大なものであった。 また，約 20 数隻は真二つに 折損（困2）したため廃棄されている。

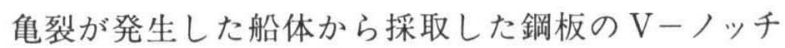
シャルピー衝撃試験結果より, 損傷発生時の温度で, 吸 収エネルギーを $15 \mathrm{ft} \cdot \mathrm{lb}(2.1 \mathrm{kgf} \cdot \mathrm{m})$ 以上有している鋼

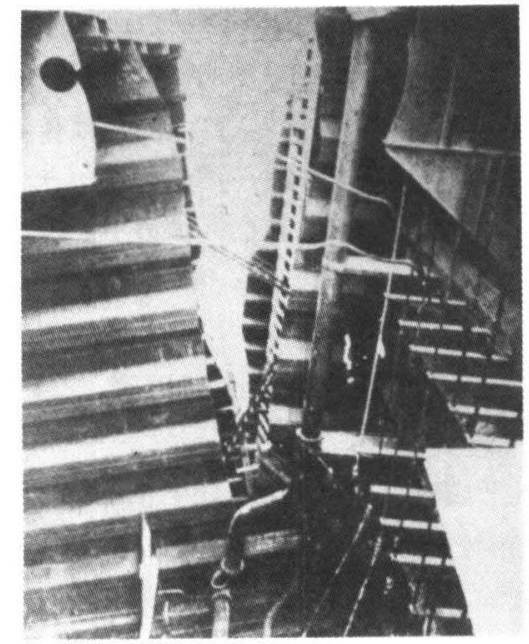

図 2 戦時標準船 Schenectady 号の破損状況 (1943（昭. 18）年 1 月)

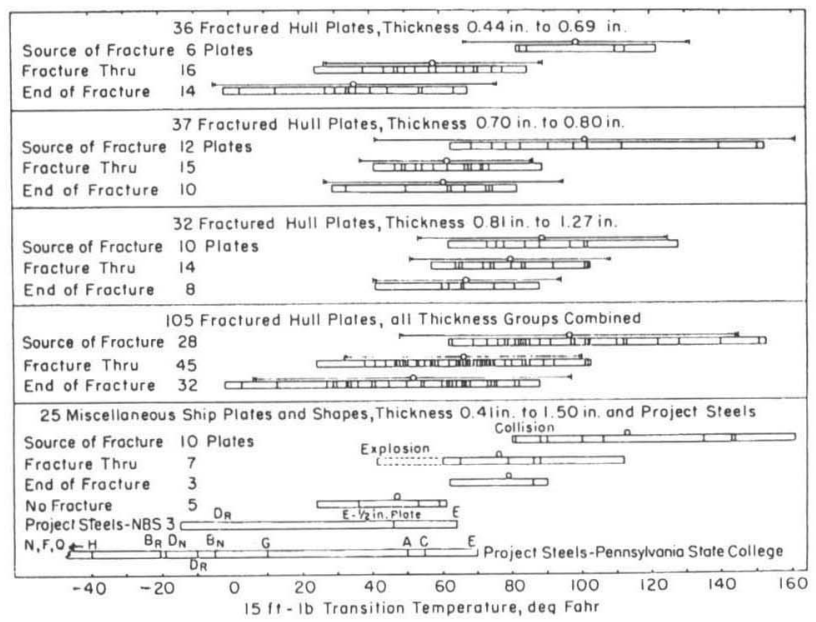

図 3 破損した船体用鋼板の $15 \mathrm{ft} ・ \mathrm{lb}$ 遶移温度
板からは，亀裂は発生しにくいことが明らかになった (困 3) ${ }^{4}$.

すなわち, 大型溶接構造物（As Weld）を建造すると き，その構造物の最低使用温度で $15 \mathrm{ft} \cdot \mathrm{lb}(2.1 \mathrm{kgf} \cdot \mathrm{m})$ 以上の $\mathrm{V}$ ーノッチシャルピー吸収エネルギーを有して いる鋼材を使用しておけば，いきなり真二つになるよう な損傷は起こらないであろうということが明らかになっ たわけである。

約 1,000 隻 (建造した 5 隻に 1 隻の割合)にも及ぶ破損 は，戦時中の混乱期とはいえ，あまりにも大きな損害で あったといえよう。その代償として“ $15 \mathrm{ft} \cdot \mathrm{lb}(2.1 \mathrm{kgf} \cdot$ m) 遷移温度クライテリオン”が残ったわけである.

\section{Avanti 号の破損例}

米国で建造された戦時標準船とほぼ同時期に、ヨー ロッパ(スウェーデン) で建造されたタンカーAvanti 号 の破損例について紹介する.

タンカーAvanti 号 (15,700 D.W.T.) が, 原油を満載し て，ニューギニアのジュランから岩国に向け北上中，1953 年 (昭和 28 年) 1 月 8 日, 奄美大島沖で船体を 2 分割する 破損事故を起こした (図 4) ${ }^{1,2,5}$. 船体前半分は沈没したが, 後半分が米海軍により救難され, 神戸港に曳航された.

その後, 再生工事が現三菱重工業（株）長崎造船所で 行なわれ, 1955 年 (昭和 30 年) 1 月 31 日, 進和丸とし て再度就航した。

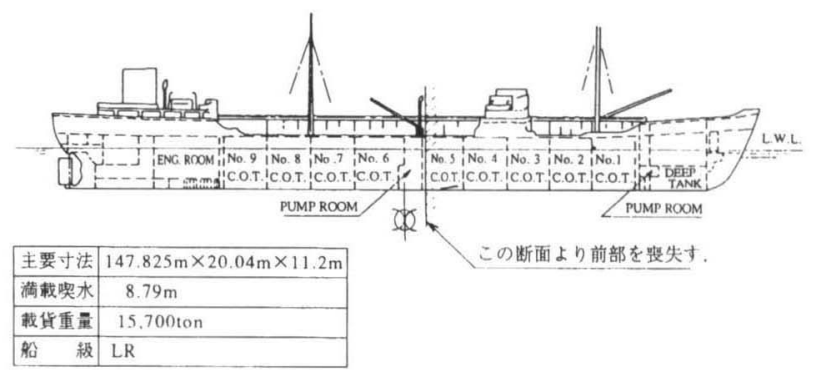

図 4 Avanti 号破損の概要（1953（炤. 28）年1月 8 日)

Avanti 号は, 1946 年 (昭和 21 年) 4 月，スウェーデン の造船所で竣工したノルウェーのタンカーであった。

第二次世界大戦末期の混乱時に建造されたため, 使用 されていた鋼板の破壊䩲性值は低く, しかも, 重要部材 である上甲板で，使用鋼板の圧延方向が船体横方向に配 置されていた。また，縦隔壁の上端が，上甲板の間に挟 み込まれており，縦隔壁の上端两面が，それぞれ上甲板 と溶接されているなど，適用されていた溶接技術も含 め，今日では想像を絶するようなものであった.

船体重要部材の $\mathrm{V}$ ーノッチシャルピー吸収エネル ギ一は, $0^{\circ} \mathrm{C} て ゙ ~ 1.0 \mathrm{kgf} \cdot \mathrm{m}$ 程度であり，溶接部は大きな 欠陥だらけで，ほとんどが JIS 5〜6級であった。 
今日想像すると, これらの溶接欠陥から疲労龟裂が発 生・成長し, 限界龟裂長さに到達して, 脆性不安定破壊 を起こし，船体を 2 分割したものと考えられる.

壊れるべくして壊れた。自然現象は正直である。ま た，絶対に我慢もしてくれない。

\section{Ohio 号の破損例}

1966 年（昭和 41 年） 4 月頃, 貨物船 Ohio 号が, 韓国 釜山沖で衝突事故を起こした。

第 2 船倉の左舷に, 船底で中心線付近まで相手の船体 が突入するという, 非常に大きな損傷を受けたが, 船体 は 2 分割せずに，生き残った (困 5 $)^{1,2)}$.

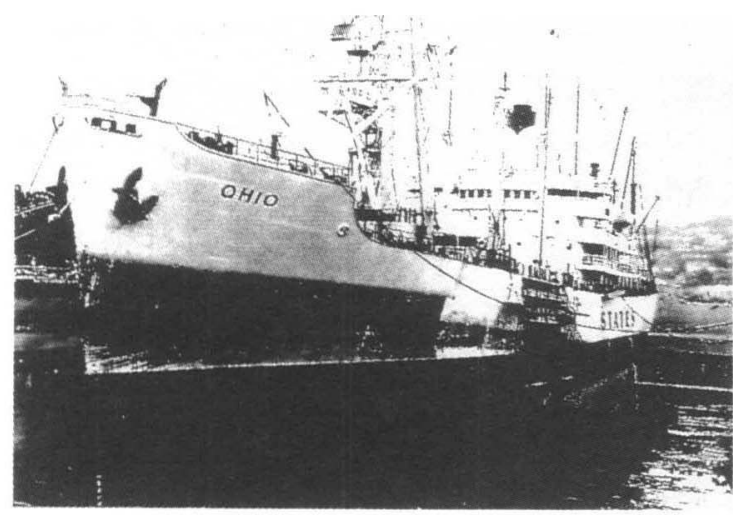

図 5 Ohio 号の破損状況 (1966 (昭. 41) 年 4 月)

Ohio 号は, 1944 年（昭和 19 年）に，米国の造船所て 建造された戦時標準船の 1 隻であった。建造時は完全溶 接構造であった上甲板部に，その後リリベットシームを 追設する改造工事が行なわれており，しかも，衝突後， 相手の船体を引き離した直後に，破口にデリックブーム を渡して補強するという，機転のきいた処置も効を奏 し，2分割を免れたわけである。

当然のこととは言え，クラックアレスターとしてのリ ベットシームの威力が認識できた事例である.

\section{6. 金清丸の破損例}

1969 年 (昭和 44 年) 1 月 8 日, 門司から十ホトカに向け 日本海を北上中の木材運搬船金清丸（7, 292 D. W. T.）の 右舷上甲板全幅が脆性不安定破壊を起こした（図 6) ${ }^{1,2,5)}$. 破壊発生時の温度は, $-1{ }^{\circ} \mathrm{C}$ 程度であったと推定され ている。脆性不安定亀裂の起点は，ハッチのトップコー ミング内側のカバープレート突合せ溶接部の溶接欠陥で あった。この溶接欠陥は，設計上の強度部材ではないの で，一寸付いていれば良いとの考えで溶接され，板厚の 半分程度未溶着部が残っていたものであった。上甲板を 伝播した脆性不安定亀裂は，舷縁に至り上甲板のストリン
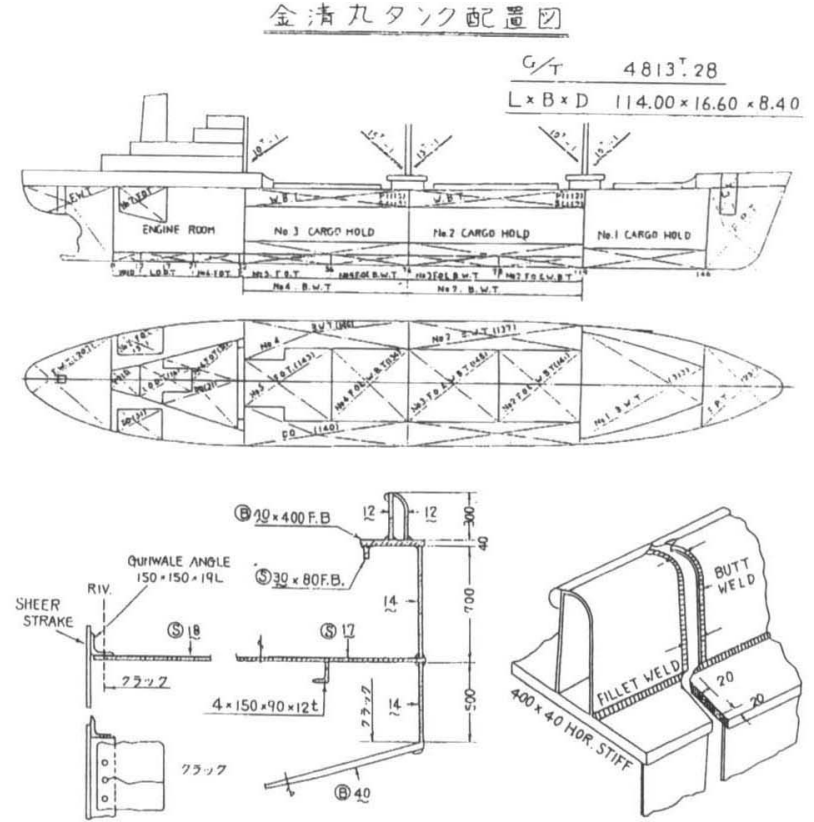

図 6 金清丸破損の概要（1969（昭. 44）年 1 月 8 日）

ガーアングル固着用のリベットホールで停止していた。舷 縁のリベットシームが，本船を生き残らせたのである。

応力条件など諸条件がかなり明確に把握できたので, 本船脆性不安定破壊例から得られた知見は多かった。

溶接で接続すれば，“一枚板”。当然“力”は流れ込む.

脆性不安定龟裂が発生すれば, 構造不連続部か高鞀性 材の挿入が無い限り，絶対に停止しない.

\section{7. 聖水大橋の破損例}

1994 年 (平成 6 年) 10 月 21 日午前 7 時 40 分頃, 韓 国・ソウル市で発生した, 聖水大橋の橋桁崩壊・落下事 故尚について紹介する。

落下した橋析は，H 型鋼の Face to Faceに通したピ ンによって両側の橋桁に吊り下げられていた（図7)。こ の $\mathrm{H}$ 型鋼は, Face to Faceにピンを通すために, Web Plateを切り取り, Face Plateが増厚されていた。この, 増厚されていたFace Plateの突合せ溶接部が，ごく表 層部のみしか溶接されていなかったのである。すなわ ち, $\mathrm{H}$ 型鋼の Face Plate の突合せ溶接部は, ごく表層 部以外未溶着であったのである（図 8, 図 9).

開先が加工されていなかったということは，充分な溶 接をする意志がなかったものと認めざるを得ない. 32 名 の犠牲者は，あまりにも大きな損害であった。

内部の未溶着部から，溶接金属部に瘦労亀裂が発生・ 進展してFace Plate が破断し，同時にWeb Plateも破 断したものであった。

自然現象は絶対に嘘はつかない。また，絶対に我慢も してくれない. 


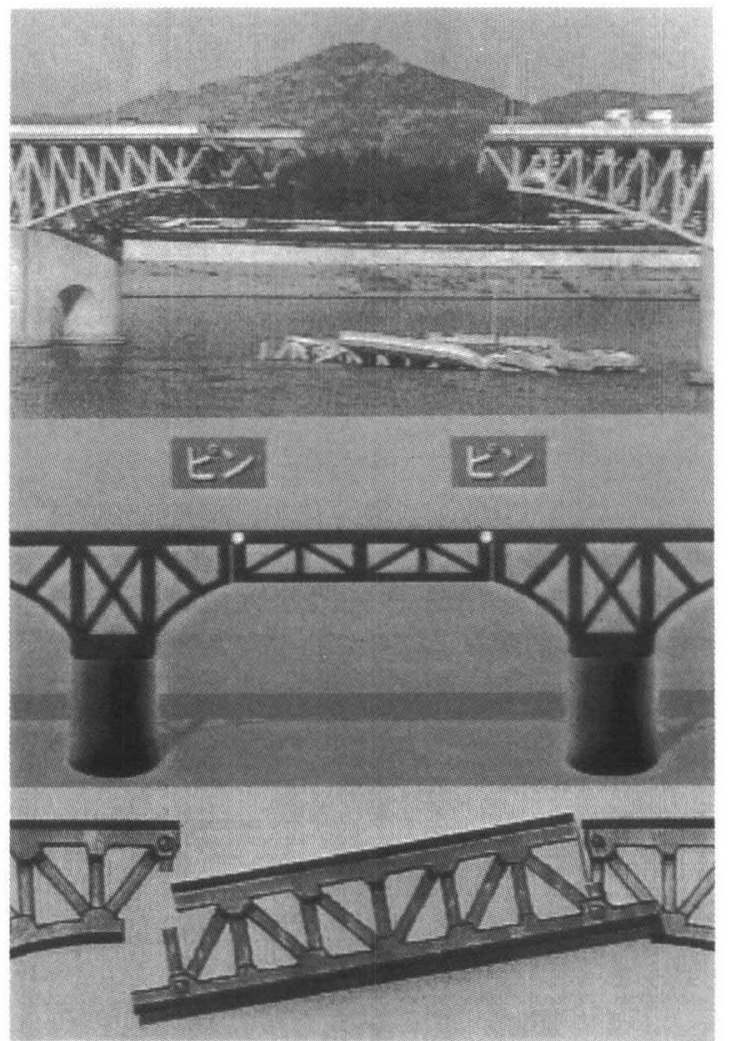

図 7 橋析落下の状況

\section{Alexander L. Kielland 号の破損例}

船舶に比へてて不静定程度の次数が低い海洋構造物は, 疲労亀裂が原因となって大損傷を招く危険性は大きいと 言わざるを得ない.

1980 年 (昭和 55 年) 3 月 27 日午前 6 時 30 分頃, 北海 で発生したペンタゴン (5 本脚) 型半潜水型石油掘削リグ Alexander L. Kielland 号の破損・転覆事故（図 10）は, 水平支えパイプの水中聴音器サポートフランジ管取り付 け溶接部の欠陷から発生した疲労亀裂が原因であっ $た^{1,2,5)}$.

事故発生時, 本リグはホテルとして使用されていたた

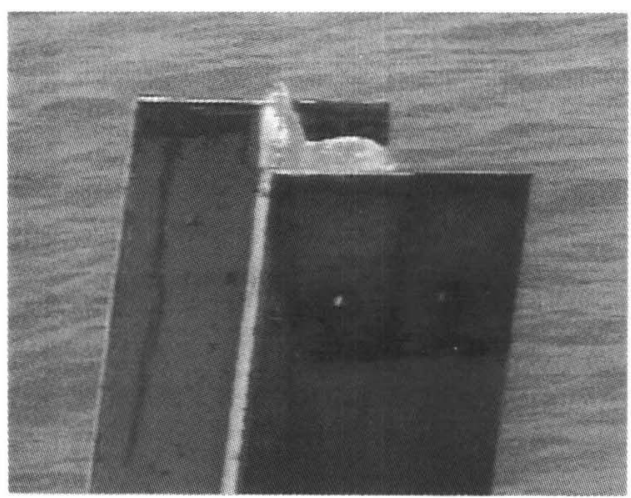

図 8 破断した $\mathrm{H}$ 型鋼

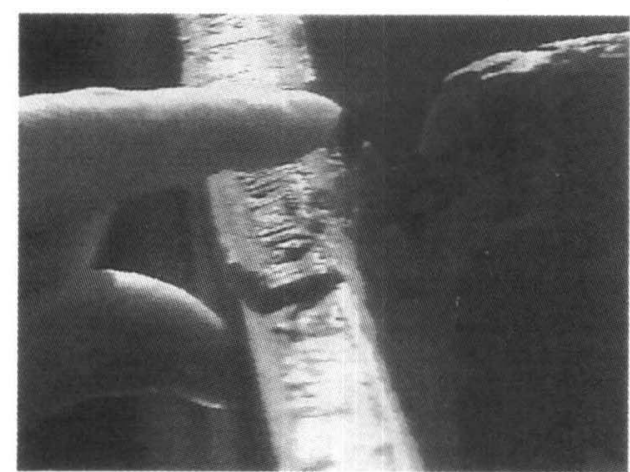

図 9 Face Plate 突合せ溶接部の未溶着部

め，212 名中 123 名が死亡するという大惨事になった。 本リグは, 1976 年 (昭和 51 年) にフランスの造船所で 建造されたものである.

直径 $2.6 \mathrm{~m}$ 程度の水平支えパイプに加工された丸穴 に, 外径 $325 \mathrm{~mm} \cdot$ 板厚 $20 \mathrm{~mm}$ - 長さ $228 \mathrm{~mm}$ の水中聴音 器サポートフランジ管を差し込み, すみ肉溶接してあっ たが, このすみ肉溶接のサポートフランジ管側熱影響部 に，溶接中あるいは溶接後しばらくして割れが発生し， その割れから疲労亀裂が発生したものと断定された。疲 労亀裂の起点になっていたこれらの割れの中に塗料が検 出されたことから, 建造時に発生した割れであると断定 されたのである.

ちょっとした付加物であるから“まあよいだろう”と

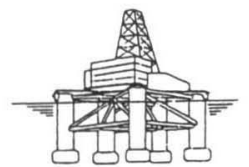

(1) 正常状焽

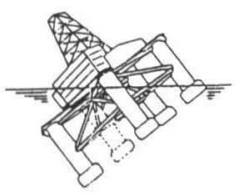

(3) 40 度顿斜

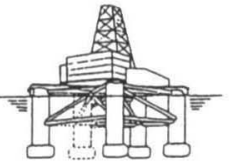

(2) 歫1本が破断

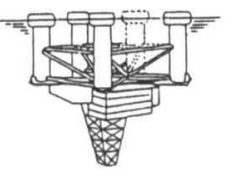

(4) 轻 覆
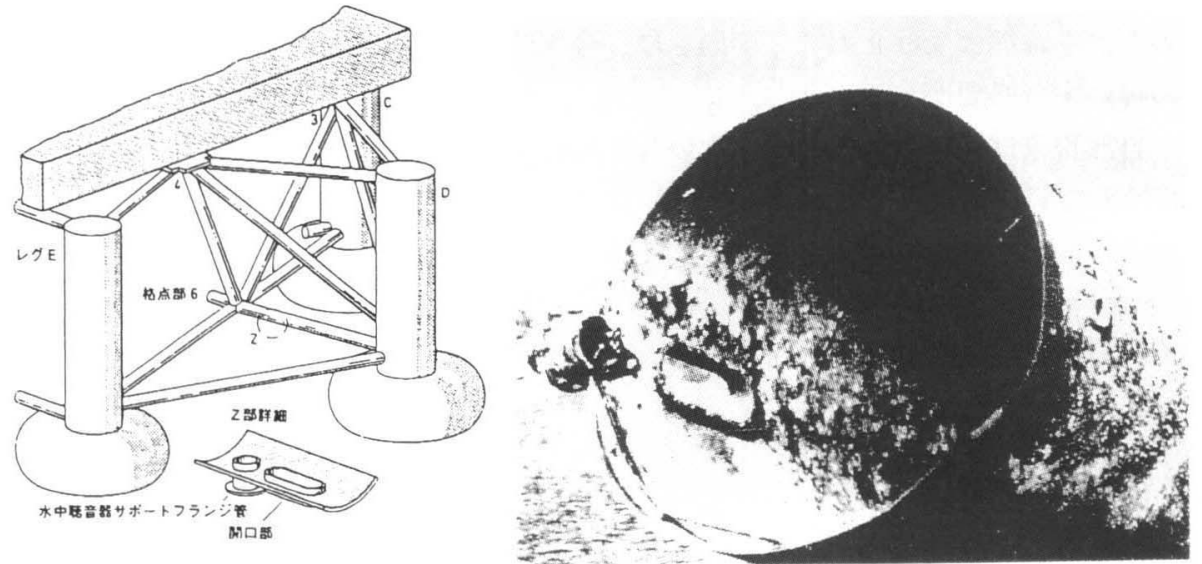

図 10 Alexander L. Kielland 号の破損・転覆事故の概要（1980（昭. 55）年 3 月 27 日） 
いうことで，施工も検査もきちんとされなかったのでは ないかと考えざるを得ない。“盲点をつかれた”例である j.

自然現象は絶対に我慢してくれない。

\section{9. 阪神・淡路大震災での破損例}

1995 年 (平成 7 年) 1 月 17 日午前 5 時 46 分の, 阪神・ 淡路大地震による未會有の大震災（図 11, 図 12） ${ }^{2,3}$ は 身近な事例として, 工学の世界に幾多の貴重な教訓を残 した.

従来, 上下方向の柱・鉄筋などに, 大きな引張荷重が 負荷されるとは予想されていなかったであろう。倒壊し た高速道路の橋脚では，圧接部で切断された上下方向の 鉄筋が曲がっていないのである（図 11）。

これは, 大地震のごく初期に, 上下方向に大きな引張 荷重を受けて切断されたものであると考えられる。

また, 図 12 のビルの中央層が崩壊した例は, 崩壊し た部分で，上下方向の柱が大地震のごく初期に切断さ れ，その後，切断部より上層部が落下し，当該層が崩壊 したものと考えられる.

上下方向の柱・鉄骨といえども，大きな引張荷重が負 荷されたのである，使用鋼材に対しては，“強さ・弱さ” のみでなく、“粘っこさ・脆さ”についても充分考慮する 必要があり, とくに溶接部・圧接部の欠陥(応力集中) · 強度・破壊靱性に対しては，充分な配慮が必要であると いう無言の証言である。

未會有の大損害が残してくれた教訓は, 謙虚に受け止 め, 早急に, 今後の糧にしなくてはならない.

\section{0. おわりに}

橋梁・船舶・海洋構造物などの大型溶接構造物で発生 した破損例, また, 阪神 - 淡路大震災での破損例を数例 紹介した。これらの破損例は, 貴重な実物実験結果であ ク, 納得するまで, 観察·思考・観察・思考…ㄴ.. そ の教訓を謙虚に受け止めて, 前向きに, 合理的に, 今後 の糧にする必要がある。

自然現象は, 絶対に嘘をつかないし, 絶対に我慢もし てくれない, 要は, 設計・建造あるいはメンテナンス担 当者の能力次第ですべてが決まるのである.

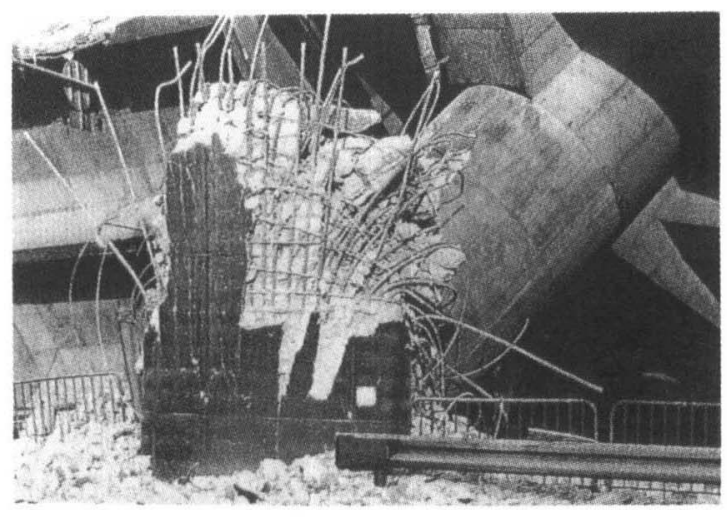

図 11 切断された上下方向の鉄筋

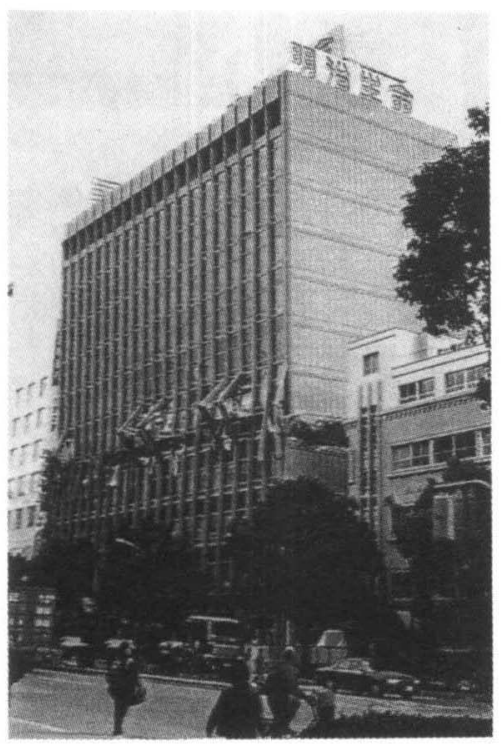

図 12 中央層が崩壊したビル

\section{参 考 文 献}

1) 矢島 浩 : 大型構造物の損傷例とその教訓, 西部造船会会 報 第 90 号 (1995. 8), pp. 245-251.

2）矢島 浩：溶接構造物における破壊事例とその教訓，溶接 技術 第 45 巻 第 1 号 (1997), pp. 90-96.

3) 日本建築学会・土木学会編：1995 年阪神・淡路大震災スラ イド集, 丸善 (株).

4) ASTM: Symposium on Effect of Temperature on the Brittle Behavior of Metals with Particular Reference to Low Temperatures, ASTM STP No. 158 (1953).

5) 矢島 浩: 連载講義 溶接構造の損傷とその防止, II-6 船 舶・海洋構造物の損傷とその对策, 溶接学会誌 第 53 巻 第 1 号 (1984.1), pp. 14-27. 